\title{
Tree Role in Environmental Quality Amelioration of the Sapienza University of Rome Campus
}

\author{
L. Gratani*, F. Tarquini, R. Catoni \\ Department of Environmental Biology, Sapienza University of Rome, Rome, Italy \\ Email: *loretta.gratani@uniroma1.it
}

How to cite this paper: Gratani, L., Tarquini, F. and Catoni, R. (2019) Tree Role in Environmental Quality Amelioration of the Sapienza University of Rome Campus. American Journal of Plant Sciences, 10, 2096-2112.

https://doi.org/10.4236/ajps.2019.1011148

Received: October 1, 2019

Accepted: November 25, 2019

Published: November 28, 2019

Copyright $\odot 2019$ by author(s) and Scientific Research Publishing Inc. This work is licensed under the Creative Commons Attribution International License (CC BY 4.0).

http://creativecommons.org/licenses/by/4.0/

\begin{abstract}
The capability of trees growing in the Campus of Sapienza University of Rome to improve environmental quality was analyzed. Measurements of $\mathrm{CO}_{2}$ concentration, air temperature and humidity, traffic density and noise level were carried out along a transect from streets outside the Campus to sites inside. Moreover, measurements were also carried out at the Experimental Garden placed inside the Campus. In each of the considered sites, diameter at breast height, plant height and carbon stored in the tree aboveground biomass were calculated. Air temperature in summer was $5 \%$ lower inside the Campus than in the surrounding streets, while relative humidity increased by $4 \%$. $\mathrm{CO}_{2}$ concentration in winter was $11 \%$ lower inside than in the surrounding streets. Carbon stored by trees was $374 \mathrm{Mg}$ to which Pinus pinea, Cedrus deodara, Quercus ilex and Tilia $\times$ europaea contributed by $30 \%, 20 \%, 18 \%$ and $13 \%$, respectively. Moreover, noise level was $36 \%$ lower inside than in the surrounding streets.
\end{abstract}

\section{Keywords}

Air Temperature, Carbon Storage, Noise Level, Trees Species, University Campus

\section{Introduction}

The increasing interest for environmental issues and the attention of the public for the problems connected to conservation have determined a new way of understanding the greening also in relation to people's well-being [1]. There has been a transformation in the way of living with a greater attention to the quality of the life [2]. Today $57 \%$ of the world population lives in cities and it is esti- 
mated that $62 \%$ of the world population will live in urban areas by the year 2030 [3]. The rapid growth of urban areas has brought social, economic and environmental challenges [4]. Urban greening is a valuable asset for modern cities delivering key functions and benefits that enhance the quality of the life [5] [6] [7]. Urban green spaces play an important role from a social perspective by promoting physical activity, increasing people interaction [8] [9] [10] and reducing stress [11] [12]. Moreover, urban greening increases the attractiveness of communities, as well as neighborhood desirability which has been quantified in a real estate value as a "willingness to pay" [13]. Consequently, due to the range of social and environmental services they afford, urban green spaces are a public good and their availability is a core indicator for a sustainability profile [4]. Thus, the use of plants to ameliorate urban air quality has become a focus of research [6] [14] [15] [16] [17]. Vegetation that covers various segments of urban areas (i.e. public and private parks, gardens, sport fields, hedges and tree-lined avenues) contributes to air quality amelioration by reducing air pollution [18] [19] [20] and decreasing $\mathrm{CO}_{2}$ concentration, air temperature and noise level [21] [22] [23]. During the last decade, there has been considerable research effort to quantify the carbon (C) storage of urban forests worldwide [17] [24]. The above-ground biomass estimation is a key parameter in accounting for carbon storage by trees [24]. In general, trees of large size have a greater $C$ storage capability than trees of small size [25] [26] [27]. Although C stored in urban forests is relatively small in scale compare to forest stands and plantation trees, the proximity of urban forests to emission sources means that their potential C storage should not be neglected [28] [29]. In such context, the main objective of this research was to evaluate the role of tree species growing in the Campus of Sapienza University of Rome to improve environmental quality. In particular, data about $\mathrm{C}$ storage, air temperature, $\mathrm{CO}_{2}$ concentration and noise level collected inside the Campus area were compared with those collected in the surrounding streets characterized by a higher traffic level. University areas play an important role as the environment to promote and protect health of the students and staff, to create holistic health-conducive working, learning and living environments with sustainability, and to develop health promotion in teaching and research [30].

\section{Materials and Methods}

\subsection{The Study Area}

The greening of the Sapienza University of Rome Campus (hereafter called Campus) largely maintains the characteristics of the original project carried out in the 1930s. The Campus covers an area of 20.3 ha. A majority of the species are Pinus pinea L., Cedrus deodara (Roxb. Ex D. Don) G. Don, Quercus ilex L., Cupressus sempervirens L., Myrtus communis L., Arbutus unedo L., Olea europaea L., Tilia $\times$ europaea L., and Cercis siliquastrum L.

The considered tree species, on average, are 100 years old. Along the Avenue 
that connects the entrance to the Minerva Fountain, there are $Q$. ilex trees followed by $P$. pinea, $C$. deodara and $C$. sempervirens. On both sides of the Minerva Fountain, there are $Q$. ilex trees. The South and North Avenues are characterized by $T . \times$ europaea. The Experimental Garden $\left(8354 \mathrm{~m}^{2}\right.$, hereafter called Garden) borders Cesare De Lollis Street in the southern side that is characterized by high traffic level during the day. The northern side is bordered by the University Avenue, characterized by high traffic levels during the day (Figure 1). The study was carried out in the period January 2017-January 2018.

\subsection{Climate}

The study area is under a Mediterranean type of climate. The average total annual rainfall was $819 \mathrm{~mm}$, most of it distributed in autumn and winter. The mean maximum air temperature ( $T_{\max }$ ) of the hottest months (July and August) was $31.8^{\circ} \mathrm{C} \pm 0.1^{\circ} \mathrm{C}$ and the mean minimum air temperature $\left(T_{\min }\right)$ of the coldest month (January) $4.7^{\circ} \mathrm{C} \pm 1.1^{\circ} \mathrm{C}$. The mean yearly air temperature was $16.8^{\circ} \mathrm{C} \pm$ $6.6^{\circ} \mathrm{C}$ (data provided by the Lazio Regional Agency for Development and Agricultural Innovation, Meteorological Station of Rome, Lanciani Street, data for the period 2006-2017).

\section{3. $\mathrm{CO}_{2}$ Concentration, Air Temperature and Humidity, Traffic Density and Noise Level}

Measurements were carried out in four sites: Cesare De Lollis Street (site A), outside the Campus and bordering the Campus in the southern side, Garden (site B), the central area inside the Campus (site C) and University Avenue (site D), outside the Campus and bordering it in the northern side (Figure 1). $\mathrm{CO}_{2}$ concentration $(\mathrm{ppm})$, air temperature $\left(\mathrm{T}_{\mathrm{a}},{ }^{\circ} \mathrm{C}\right)$ and humidity $(\mathrm{RH}, \%)$ were monitored simultaneously by handheld tools (Rotronic, CP11). Noise level (N, dB) was monitored by portable sound level meters (Testo 816, class 2, Italy). Traffic density (i.e. number of vehicles per minute) was monitored simultaneously with microclimate, $\mathrm{CO}_{2}$ concentration and noise level in A and D sites. Measurements were carried out monthly (three sampling days per month with comparable climatic conditions, almost 3 days after the last rainfall) from 8.00 to 11.30 a.m. (traffic density peak hours, Gratani and Varone 2005) during the study period, at $1.50 \mathrm{~m}$ from the soil, according to [31].

\subsection{Plant Traits}

The number of tree per each species growing in the Campus and in the Garden was counted. Structural traits were measured on representative trees. In particular, tree diameter at breast height $(\mathrm{DBH}, \mathrm{m})$ was measured by callipers (Silvanus calliper $-65 \mathrm{~cm}$ ) or by a DBH tape (length $=20 \mathrm{~m}$ ) when the diameter was larger than $65 \mathrm{~cm}$. Plant height $(\mathrm{H}, \mathrm{m})$ was measured by electronic clinometers (Haglöf, Sweden). Trees with a diameter larger than $5 \mathrm{~cm}$ were considered [32]. Trees different age classes were selected for $P$. pinea, based on the ratio between $\mathrm{H}$ and crown height $\left(\mathrm{C}_{\mathrm{H}}, \mathrm{m}\right)$, according to [33]. $\mathrm{C}_{\mathrm{H}}$ was defined as the vertical 


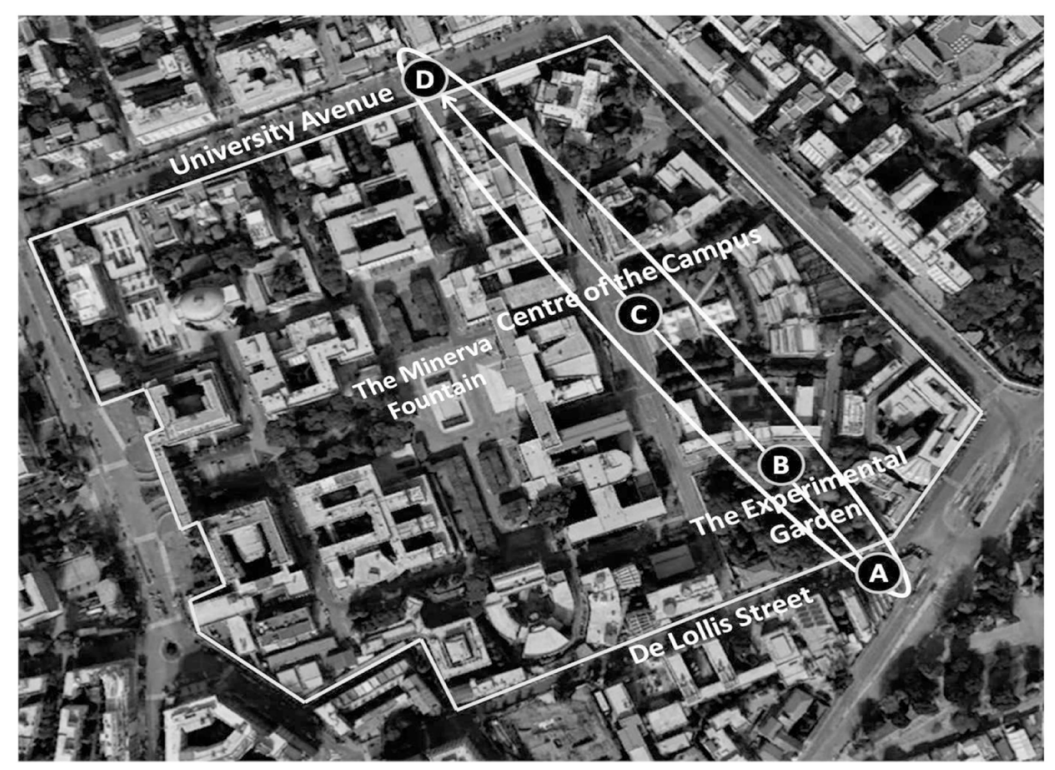

Figure 1. Map of the Sapienza University of Rome Campus. The Transect from Cesare De Lollis Street (A site), the Experimental Garden (B site), the central area inside the Campus (C site) to the University Avenue (D site) is shown. Image from google.earth.

distance from the lowest branch insertion to the highest point of the trees, according to [34].

\subsection{Aboveground Biomass and Carbon Storage}

The aboveground biomass $(\mathrm{AB})$ of the tree species was obtained by allometric equations [32] [35] [36] [37] using $\mathrm{DBH}$ and $\mathrm{H}$ for each species. If no allometric equations were found for a species, the mean value of the equations of the same genus was used. If no genus equations were found, the value from broadleaf or conifer general equations was used, according to [17].

The carbon $(C)$ stored in the aboveground biomass $\left(C_{A}\right)$ was calculated by multiplying $\mathrm{AB}$ by 0.5 [38].

\subsection{Statistical Analysis}

Differences of the means were tested by one-way analysis of variance (ANOVA) and Tukey test for multiple comparisons. All statistical tests were performed using a statistical software package (Statistica, Statsoft, USA). A correlation analysis was carried out between $\mathrm{CO}_{2}$ concentration and traffic density, and between $\mathrm{CO}_{2}$ concentration and $\mathrm{T}_{\mathrm{a}}$.

\section{Results}

\section{1. $\mathrm{CO}_{2}$ Concentration, Air Temperature and Humidity, Traffic Density and Noise Level}

The $\mathrm{CO}_{2}$ concentration trend during the study period is shown in Figure 2. The mean yearly $\mathrm{CO}_{2}$ concentration at 8.30 a.m., when traffic peaked $(27 \pm 7$ vehicles. $\mathrm{min}^{-1}$, mean value of $\mathrm{A}$ and $\mathrm{D}$ sites), was $502 \pm 47 \mathrm{ppm}$ (mean value of 


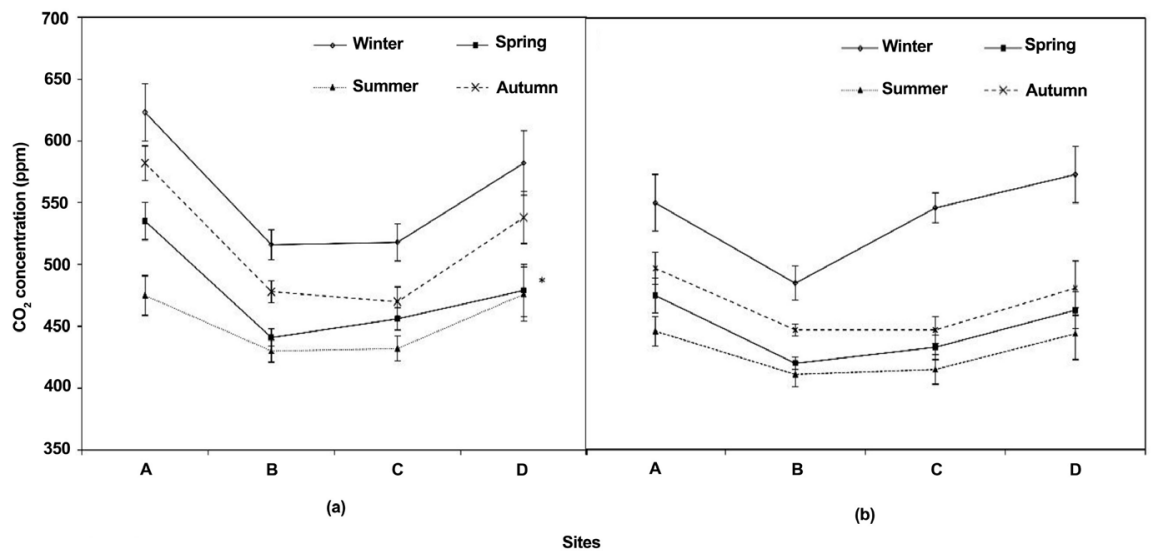

Figure 2. Carbon dioxide concentration $\left(\mathrm{CO}_{2}\right)$ monitored at 8.30 a.m. (a) and at 11.30 a.m. (b) during the study period along the transect. $\mathrm{A}=$ Cesare De Lollis Street, $\mathrm{B}=$ Experimental Garden, $\mathrm{C}=$ central area inside the Campus, $\mathrm{D}=$ the Avenue of the University. Mean value and standard deviation are shown $(n=9)$. Differences across the transect are always significant except when indicated $\left({ }^{*}\right.$, ANOVA, $\left.p<0.05\right)$.

A-B-C-D) decreasing by $6 \%$ at 11.30 a.m. (mean value of A-B-C-D). The highest values were monitored in winter $(544 \pm 23 \mathrm{ppm})$ when traffic peaked (31 \pm 6 vehicles. $\mathrm{min}^{-1}$, mean value of $\mathrm{A}$ and D) decreasing by $17 \%$ and $20 \%$ in spring and summer, respectively. The highest $\mathrm{CO}_{2}$ concentration along the transect was monitored in $\mathrm{A}$ and in $\mathrm{D}(523 \pm 60 \mathrm{ppm}$ and $505 \pm 52 \mathrm{ppm}$, respectively, mean value at 8.30 a.m. and 11.30 a.m., during the study period) and the lowest in B $(448 \pm 34, \mathrm{ppm})$. There was a significant positive correlation between $\mathrm{CO}_{2}$ concentration and traffic density $\left(\mathrm{y}=4.0083 \mathrm{x}+409.61, \mathrm{R}^{2}=0.4025, p<0.05\right)$ showing that $40 \%$ of $\mathrm{CO}_{2}$ concentration variations depended on traffic density variations.

The mean yearly $\mathrm{T}_{\mathrm{a}}$ was $20.1^{\circ} \mathrm{C} \pm 8.9^{\circ} \mathrm{C}$ (mean value of A-B-C-D) at 8.30 a.m. increasing by $27 \%$ at 11.30 a.m. (mean value of A-B-C-D). The highest $\mathrm{T}_{\mathrm{a}}$ was monitored in summer $\left(31.0^{\circ} \mathrm{C} \pm 1.8^{\circ} \mathrm{C}\right.$, mean value of $\left.\mathrm{A}-\mathrm{B}-\mathrm{C}-\mathrm{D}\right)$ at 8.30 a.m. (Figure 3) decreasing by $47 \%$ and $73 \%$ in autumn and winter, respectively. Along the transect, the lowest $\mathrm{T}_{\mathrm{a}}$ was monitored in $\mathrm{B}\left(21.4^{\circ} \mathrm{C} \pm 8.8^{\circ} \mathrm{C}\right.$, mean value at 8.30 a.m. and 11.30 a.m.) increasing by $10 \%$ in $\mathrm{A}, \mathrm{C}$ and $\mathrm{D}$ (mean value). There was a significant negative correlation between $\mathrm{CO}_{2}$ and $\mathrm{T}_{\mathrm{a}}(\mathrm{y}=-4.7597 \mathrm{x}+$ $\left.595.15, \mathrm{R}^{2}=0.63, p<0.05\right)$.

The mean yearly RH was $49 \% \pm 14 \%$ (mean value of A-B-C-D) at 8.30 a.m. decreasing by $24 \%$ (mean value of A-B-C-D) at 11.30 a.m. The lowest RH was monitored in summer $(33 \% \pm 6 \%$, mean value of $A-B-C-D)$ at 8.30 a.m., and the highest in autumn $(65 \% \pm 7 \%$, mean value of A-B-C-D). Along the transect, the highest $\mathrm{RH}$ was measured in $\mathrm{B}(46.0 \% \pm 10.0 \%$, mean value at 8.30 a.m. and 11.30 a.m. $)$ and the lowest in $\mathrm{C}(38 \% \pm 4 \%$, mean value at 8.30 a.m. and 11.30 a.m.).

The highest noise level was monitored in A and D $(80 \pm 2 \mathrm{~dB}$, mean yearly value) decreasing by $44 \%$ and $36 \%$ in $B$ and C, respectively. During the year, the highest noise level was monitored in winter $(84 \pm 2 \mathrm{~dB}$, mean value of $\mathrm{A}$ and $\mathrm{D})$ 


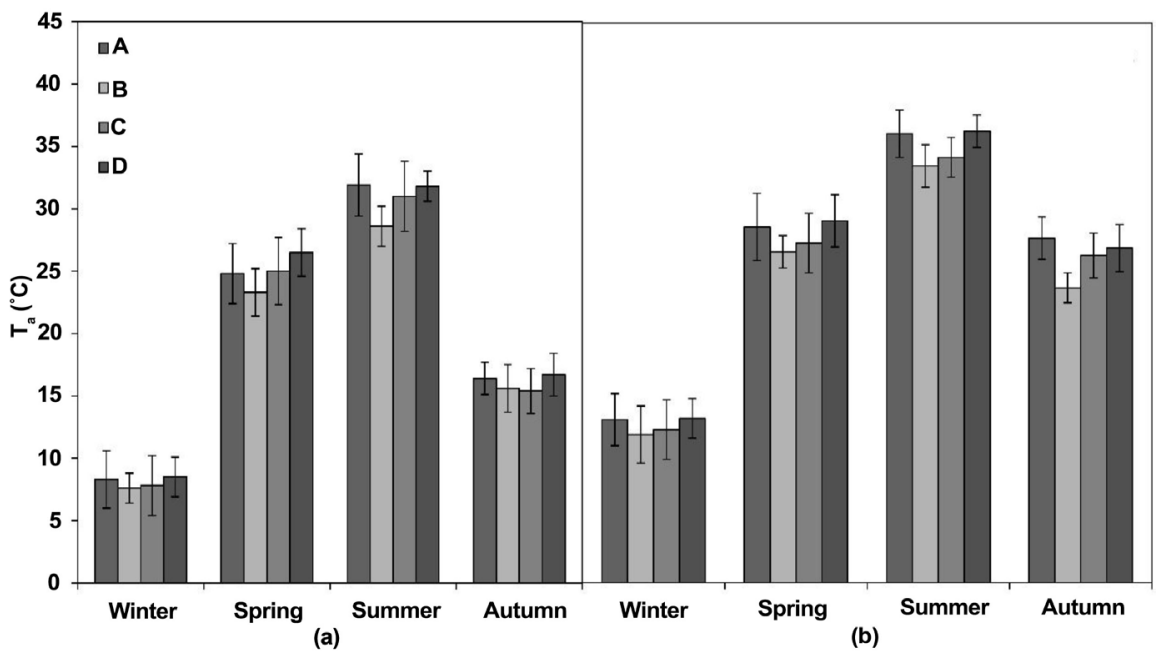

Figure 3. Air temperature $\left(T_{\mathrm{a}}\right)$ monitored at 8.30 a.m. (a) and at 11.30 a.m. (b) during the study period along the transect. $\mathrm{A}=$ Cesare De Lollis Street, $\mathrm{B}=$ Experimental Garden, $\mathrm{C}$ = central area inside the Campus, $\mathrm{D}=$ the Avenue of the University. Mean value and standard deviation are shown $(n=9)$.

when traffic peaked, decreasing by $8 \%$ and $14 \%$, in spring and summer, respectively, according to the traffic density decreasing (26\% and $39 \%$, respectively).

\subsection{Plant Traits}

Structural traits of the considered tree species growing in the Campus and in the Garden, and the tree numbers for each species are shown in Table 1 and Table 2, respectively. The total number of trees in the Campus was 647 of which $Q$. ilex, T. $\times$ europaea and $P$. pinea were $33 \%, 15 \%$ and $13 \%$, respectively. $\mathrm{H}$ ranged from $2.9 \pm 0.3 \mathrm{~m}$ (Chamaerops humilis) to $29.0 \pm 1.1 \mathrm{~m}$ (C. deodara). C. deodara had the highest DBH $(96.0 \pm 0.8 \mathrm{~cm})$ and Persea americana the lowest $(6.4 \pm 0.5$ $\mathrm{cm}$ ). $\mathrm{H}$ varied from $6.3 \pm 1.5 \mathrm{~m}$ ( 15 years), $13.0 \pm 2.3 \mathrm{~m}$ (45 years) to $24.3 \pm 5.4$ m (100 years) in P. pinea.

In the Garden there were 85 trees, covering $6040 \mathrm{~m}^{2}$ (72\% of the total Garden area) Platanus orientalis and Cinnamoum camphora showing the highest $\mathrm{H}$ (26.4 m and $23.2 \pm 6.1 \mathrm{~m}$, respectively) and Platanus orientalis the highest $\mathrm{DBH}$ $(154 \mathrm{~cm})$. Citrus spp. had the lowest $\mathrm{H}$ and DBH $(3.5 \pm 0.3 \mathrm{~m}$ and DBH $10 \pm 0.6$ $\mathrm{cm}$, respectively).

\subsection{Carbon Storage}

The total $\mathrm{C}$ stored by all the trees growing in the Campus was $372 \mathrm{Mg}$ of $\mathrm{C}$ to which those growing in the Garden contributed by $9 \%$ (Table 3 and Table 4). $P$. pinea, C. deodara, Q. ilex and T. $\times$ europaea had the highest C storage (30\%, $20 \%, 18 \%$ and $13 \%$, respectively, of the total $C$ storage in the Campus), while Bauhinia aculeata $\mathrm{C}$ storage was lower than $0.01 \%$. P. orientalis and C. camphora growing in the Garden contribute by $13 \%$ and $11 \%$, respectively to the total C storage in the Garden while Nolina longifolia (Karw. ex Schult. \& Schult. f.) Hemsl. by $0.12 \%$. 
Table 1. Structural traits and number of the considered tree species inside the Campus of the Sapienza University of Rome. $\mathrm{H}=$ plant height, $\mathrm{DBH}=$ diameter at breast height, $\mathrm{n}^{\circ}=$ number of trees.

\begin{tabular}{|c|c|c|c|c|c|}
\hline & $\mathrm{H}(\mathrm{m})$ & & $\mathrm{BH}(\mathrm{cm})$ & & $\mathrm{n}^{\circ}$ \\
\hline Species & mean & dev.st & mean & dev.st & \\
\hline Acer negundo L. & 12.00 & & 25.78 & & 1 \\
\hline Ailanthus altissima (Mill.) Swingle & 12.60 & 1.20 & 67.48 & 1.0 & 12 \\
\hline Bauhinia aculeata L. & 13.00 & & 26.10 & & 1 \\
\hline Cedrus deodara (Roxb. ex D.Don) G.Don & 29.00 & 1.10 & 95.49 & 0.80 & 35 \\
\hline Cercis siliquastrum L. & 7.28 & 0.85 & 23.87 & 0.56 & 3 \\
\hline Chamaerops humilis $\mathrm{L}$. & 2.90 & 0.30 & & & 21 \\
\hline Cinnamomum glanduliferum (Wall.) Meisn. & 15.20 & & 40.74 & & 1 \\
\hline Citrus limon (L.) Osbeck & 4.20 & & 12.10 & & 1 \\
\hline Citrus $\times$ aurantium $\mathrm{L}$. & 5.80 & 1.20 & 27.69 & 0.96 & 6 \\
\hline Cupressus arizonica Greene & 16.60 & & 38.20 & & 1 \\
\hline Cupressus sempervirens $\mathrm{L}$. & 18.19 & 0.80 & 50.93 & 0.10 & 12 \\
\hline Eriobotrya japonica (Thunb.) Lindl. & 7.60 & 1.0 & 22.28 & 0.86 & 11 \\
\hline Ficus carica L. & 7.50 & 0.90 & 40.11 & 0.56 & 4 \\
\hline Hibiscus syriacus $\mathrm{L}$. & 3.30 & & 10.19 & & 1 \\
\hline Ligustrum lucidum W. T. Aiton & 7.90 & 1.50 & 56.34 & 0.59 & 34 \\
\hline Magnolia grandiflora L. & 15.00 & 2.30 & 73.21 & 1.30 & 4 \\
\hline Myrtus communis $\mathrm{L}$. & 5.90 & 0.87 & 20.00 & 0.53 & 15 \\
\hline Olea europaea L. & 3.00 & 0.67 & 19.42 & 0.41 & 18 \\
\hline Paulownia tomentosa Steud. & 15.75 & & 55.70 & & 1 \\
\hline Persea americana Mill. & 4.30 & 0.93 & 6.37 & 0.50 & 2 \\
\hline Phoenix canariensis Chabaud & 8.50 & & & & 1 \\
\hline Phoenix dactylifera L. & 8.60 & 1.7 & & & 3 \\
\hline Picea abies (L.) H.Karst. & 14.70 & 1.62 & 26.42 & 1.69 & 3 \\
\hline Pinus pinea L. (100 year-old-tree) & 24.30 & 5.4 & 85.94 & 2.3 & 47 \\
\hline Pinus pinea L. (45 year-old-tree) & 13.00 & 2.3 & 42.05 & 2.4 & 14 \\
\hline Pinus pinea L. (15 year-old-tree) & 6.30 & 1.5 & 15.00 & 0.96 & 22 \\
\hline Pinus sylvestrisL. & 15.20 & 1.51 & 38.83 & 1.31 & 5 \\
\hline Platanus $\times$ hispanica Mill. ex Münchh. & 22.00 & 1.5 & 86.58 & 0.98 & 3 \\
\hline Platycladus orientalis (L.) Franco & 5.50 & 0.87 & 32.47 & 0.86 & 7 \\
\hline Populus nigra L. & 16.00 & 1.90 & 60.48 & 0.96 & 10 \\
\hline Prunus armeniaca $\mathrm{L}$. & 5.20 & 0.65 & 14.32 & 0.35 & 2 \\
\hline Prunus avium (L.) L. & 9.00 & 0.52 & 28.01 & 0.34 & 3 \\
\hline Prunus cerasifera Ehrh. & 5.00 & & 12.73 & & 1 \\
\hline Prunus domestica $\mathrm{L}$. & 4.90 & & 13.05 & & 1 \\
\hline Prunus dulcis (Mill.) D.A.Webb & 9.60 & 0.36 & 51.57 & 0.54 & 3 \\
\hline Prunus laurocerasus $\mathrm{L}$. & 6.80 & 0.42 & 13.37 & 0.84 & 5 \\
\hline Prunus persica (L.) Batsch & 4.00 & & 13.69 & & 1 \\
\hline Prunus serrulata Lindl. & 7.45 & 0.54 & 24.83 & 0.36 & 6 \\
\hline Punica granatum L. & 5.80 & 0.23 & 10.19 & 0.54 & 13 \\
\hline Quercus ilex $\mathrm{L}$. & 7.50 & 0.68 & 44.56 & 0.28 & 215 \\
\hline Robinia pseudoacacia L. & 11.70 & & 49.02 & & 1 \\
\hline Sabal palmetto (Walter) Lodd. ex Schult. \& Schult.f. & 4.50 & 0.56 & & & 2 \\
\hline Tilia $\times$ europaea L. & 11.20 & 0.56 & 76.39 & 0.25 & 95 \\
\hline
\end{tabular}


Table 2. Structural traits of the tree species growing in the Experimental Botanical Garden of the Sapienza University of Rome. $\mathrm{H}=$ plant height, $\mathrm{DBH}=$ diameter at breast height, $\mathrm{n}^{\circ}=$ number of trees.

\begin{tabular}{|c|c|c|c|c|c|}
\hline Experimental Botanical Garden & $\mathrm{H}(\mathrm{m})$ & & $\mathrm{BH}(\mathrm{cm}$ & & $\mathbf{n}^{\circ}$ \\
\hline Species & mean & dev.st & mean & dev.st & \\
\hline Abies alba Mill. & 12 & & 29.28 & & 1 \\
\hline Aesculus hippocastanum $\mathrm{L}$. & 13 & & 52.84 & & 1 \\
\hline Albizzia julibrissin Durazz. & 13.5 & & 69.07 & & 1 \\
\hline Acacia horrida (L.) Willd. & 12 & & 32.79 & & 1 \\
\hline Acer pseudoplatanus $\mathrm{L}$. & 16.7 & & 52.84 & & 1 \\
\hline Araucaria bidwillii Hook. & 17.5 & & 53.79 & & 1 \\
\hline $\begin{array}{l}\text { Brachychiton acerifolius } \\
\text { (A.Cunn. ex G.Don) F. Muell. }\end{array}$ & 11.45 & 5.16 & 31.8 & 15.8 & 2 \\
\hline Cedrus atlantica (Endl.) Manetti ex Carrière & 14 & & 48.06 & & 1 \\
\hline Celtis australis $\mathrm{L}$. & 11.98 & 2.16 & 58.15 & 9.25 & 4 \\
\hline Celtis bungeana Blume & 7.2 & & 42.0 & & 1 \\
\hline Ceratonia siliqua L. & 6.6 & 3.9 & 32.7 & 22.6 & 2 \\
\hline Chamaerops humilis $\mathrm{L}$. & 4.4 & 0.12 & & & 6 \\
\hline Cinnamomum camphora (L.) J. Presl & 23.2 & 6.08 & 95.49 & 41.41 & 2 \\
\hline Citrus $\times$ aurantium $\mathrm{L}$. & 2.3 & 1.1 & 6.32 & 2.81 & 3 \\
\hline Citrus deliciosa Ten. & 1.7 & 0.4 & 5.0 & 1.41 & 4 \\
\hline Citrus limon (L.) Osbeck & 2.1 & 0.3 & 5.9 & 2.10 & 3 \\
\hline Citrus maxima (Burm.) Merr. & 3.5 & & 9.6 & & 1 \\
\hline Cupressus sp. & 21.3 & 1.1 & 63.2 & 1.5 & 2 \\
\hline Diospyros lotus L. & 13.5 & & 51.9 & & 1 \\
\hline Eriobotrya japonica (Thunb.) Lindl. & 5 & & 29.92 & & 1 \\
\hline Eucaliptus viminalis Labill. & 15.1 & 0.14 & 67.91 & 0.30 & 2 \\
\hline Fagus sylvatica $\mathrm{L}$. & 13.78 & 4.16 & 43.00 & 20.36 & 4 \\
\hline Firmiana simplex (L.) W. Wight & 9.3 & & 30.2 & & 1 \\
\hline Fraxinus excelsior $\mathrm{L}$. & 13 & & 40.11 & & 1 \\
\hline Ginkgo biloba L. & 19.1 & 0.28 & 45.59 & 0.80 & 2 \\
\hline Jacaranda mimosifolia D. Don & 10.7 & & 41.06 & & 1 \\
\hline Magnolia grandiflora $\mathrm{L}$. & 11.0 & & 34.4 & & 1 \\
\hline Melia azedarach $\mathrm{L}$. & 14.5 & & 48.38 & & 1 \\
\hline Morus alba L. & 12.5 & & 75.76 & & 1 \\
\hline Morus nigra L. & 12.4 & & 57.61 & & 1 \\
\hline $\begin{array}{l}\text { Nolina longifolia (Karw. ex Schult. \& Schult.f.) } \\
\text { Hemsl. }\end{array}$ & 7.2 & & 63.7 & & 1 \\
\hline Olea europaea L. & 6.9 & 0.1 & 31.20 & 0.9 & 2 \\
\hline P. pinea $\mathrm{L}$. & 19.9 & 0.1 & 80.9 & 0.3 & 2 \\
\hline Phoenix canariensis Chabaud & 17.2 & 0.8 & & & 2 \\
\hline Phytolacca dioica L. & 9.3 & 0.8 & 42.3 & 3.2 & 2 \\
\hline Pinus brutia Ten. & 17.0 & & 53.2 & & 1 \\
\hline
\end{tabular}




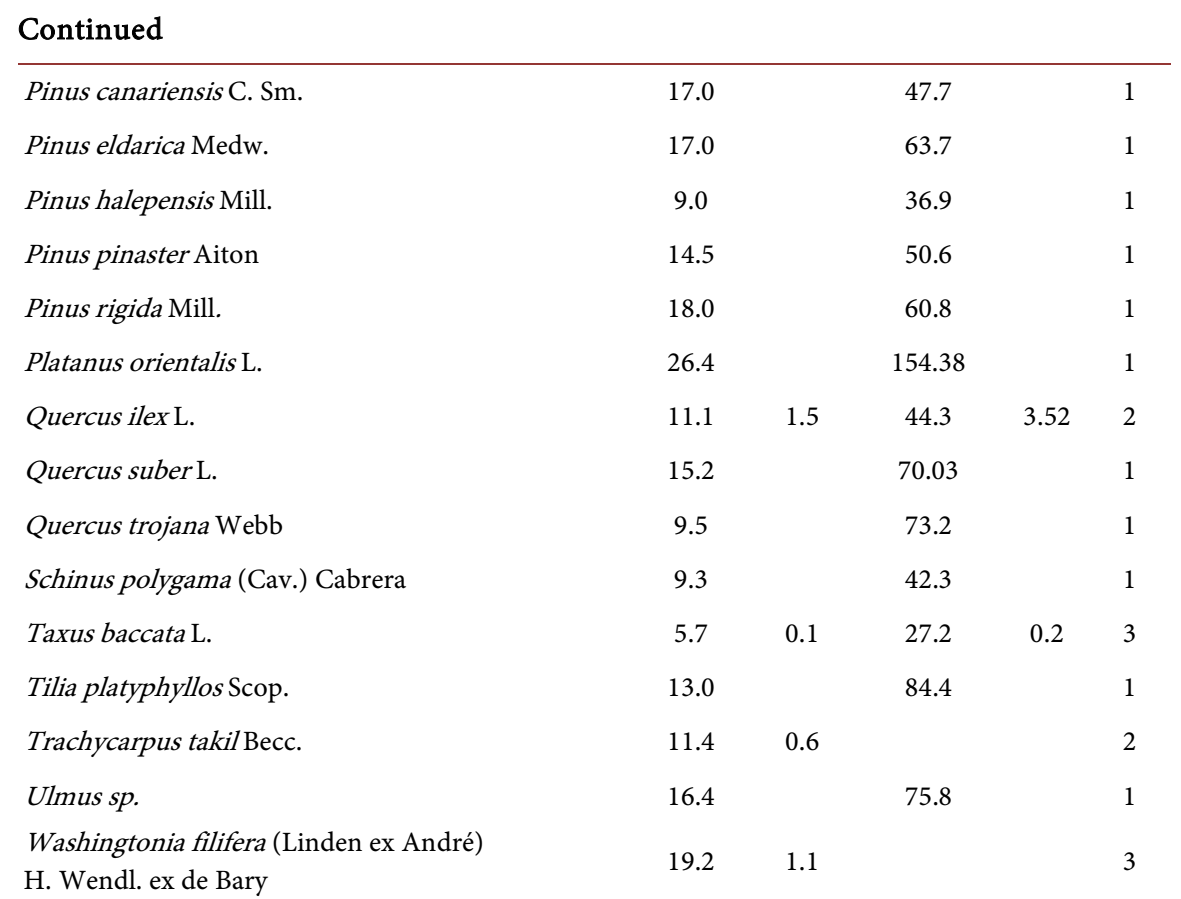

\section{Discussion}

Trees are keystone structures in forest ecosystems, including those in urban areas [15] [16] [39] [40]. On the whole, the results highlight that in the Campus there are 41 tree species and a total of 647 trees. In the Garden there are 85 trees. The most abundant species are $P$. pinea, $Q$. ilex, $T . \times$ europaea, $C$. deodara and $C$. sempervirens. There are centenarian $P$. pinea (47 trees) and C. deodara (35 trees) already present in the 1930s. Q. ilex (215 trees) and T. $\times$ europaea (86 trees) characterize the tree-lined avenues inside the Campus.

Among the benefits provided by greening, trees are excellent regulators of air temperature, heat and dampness in urban surroundings [41]. In particular, tree structure defines patterns of light-capturing areas and air temperature buffering effects of the canopy [42] [43] [44], which contribute to mitigate the urban "heat island" [45]. The trees growing in the Campus contribute to decrease air temperature in summer by $8 \%$ and $3 \%$ at the Garden (site B) and in the center of the Campus (site C) than the surrounding streets (sites A and D), while RH increases by $23 \%$ and by $9 \%$, respectively. In Autumn $\mathrm{T}_{\mathrm{a}}$ decreases by $7 \%$ and $6 \%$ at $\mathrm{B}$ and $\mathrm{C}$ sites, while in winter by $7 \%$ and $10 \%$, respectively. The urban $\mathrm{C}$ cycle has its own driving forces, significantly different from those of natural ecosystems [46]. Humans and automobile activity produced more than $80 \%$ input of $\mathrm{CO}_{2}$ into the urban environment [46] and motor vehicles are significant sources of air pollution emissions [18]. C is stored in plant tissues at different quantities depending on factors such as age [47], growth rate and leaf life span [14] [16], thus contributing to decrease the atmospheric $\mathrm{CO}_{2}$ concentration. Trees with a large crown store more $C$ than trees with a small crown [15]. In particular, the total $C$ stored by trees growing in the Campus is $374 \mathrm{Mg}$ of C to which C. deodara, $Q$. 
Table 3. The aboveground biomass $(\mathrm{AB})$, carbon stored in the aboveground biomass $\left(\mathrm{C}_{\mathrm{A}}\right)$ and the total carbon stored for each of the considered species inside the Campus of the Sapienza University of Rome.

\begin{tabular}{|c|c|c|c|}
\hline Species & $\mathrm{AB}(\mathrm{Kg})$ & $\mathrm{C}_{\mathrm{A}}(\mathrm{Kg})$ & $\mathrm{C}_{\text {Atot }}$ per species $(\mathrm{Mg})$ \\
\hline Acer negundo L. & 217 & 108.4 & 0.108 \\
\hline Ailanthus altissima (Mill.) Swingle & 888 & 444.1 & 5.329 \\
\hline Bauhinia aculeata L. & 0.255 & 0.13 & 0.00013 \\
\hline Cedrus deodara (Roxb. ex D. Don) G. Don & 4222 & 2111.0 & 73.88 \\
\hline Cercis siliquastrum $\mathrm{L}$. & 112 & 56.1 & 0.168 \\
\hline Chamaerops humilis $\mathrm{L}$. & 35 & 17.5 & 0.367 \\
\hline Cinnamomum glanduliferum (Wall.) Meisn. & 418.3 & 209.2 & 0.209 \\
\hline Citrus limon (L.) Osbeck & 32.7 & 16.4 & 0.016 \\
\hline Citrus $\times$ aurantium $\mathrm{L}$. & 128 & 63.9 & 0.384 \\
\hline Cupressus arizonica Greene & 639.9 & 320.0 & 0.320 \\
\hline Cupressus sempervirens $\mathrm{L}$. & 1217 & 608.6 & 7.304 \\
\hline Eriobotrya japonica (Thunb.) Lindl. & 103 & 51.4 & 0.565 \\
\hline Ficus carica $\mathrm{L}$. & 258 & 129.2 & 0.517 \\
\hline Hibiscus syriacus $\mathrm{L}$. & 23 & 11.7 & 0.012 \\
\hline Ligustrum lucidum W. T. Aiton & 466 & 232.8 & 7.917 \\
\hline Magnolia grandiflora L. & 1182 & 591.2 & 2.365 \\
\hline Myrtus communis $\mathrm{L}$. & 79 & 39.3 & 0.589 \\
\hline Olea europaea L. & 62 & 31.0 & 0.558 \\
\hline Paulownia tomentosa Steud. & 749 & 374.5 & 0.375 \\
\hline Persea americana Mill. & 9 & 4.7 & 0.009 \\
\hline Phoenix canariensis Chabaud & 89 & 44.6 & 0.223 \\
\hline Phoenix dactylifera $\mathrm{L}$. & 90 & 45.1 & 0.045 \\
\hline Picea abies (L.) H. Karst. & 195.8 & 97.9 & 0.294 \\
\hline Pinus pinea L. (100 year-old-tree) & 4519 & 2259.6 & 106.20 \\
\hline Pinus pinea L. (45 year-old-tree) & 579 & 289.6 & 4.05 \\
\hline Pinus pinea L. (15 year-old-tree) & 36 & 18.1 & 0.40 \\
\hline Pinus sylvestris $\mathrm{L}$. & 509 & 254.5 & 1.273 \\
\hline Platanus $\times$ hispanica Mill. ex Münchh. & 2238 & 1119.1 & 3.357 \\
\hline Platycladus orientalis (L.) Franco & 183.1 & 91.5 & 0.641 \\
\hline Populus nigra L. & 880 & 439.9 & 4.399 \\
\hline Prunus armeniaca $\mathrm{L}$. & 45 & 22.6 & 0.045 \\
\hline Prunus avium (L.) L. & 160 & 80.1 & 0.240 \\
\hline Prunus cerasifera Ehrh. & 37 & 18.5 & 0.019 \\
\hline Prunus domestica $\mathrm{L}$. & 38 & 19.2 & 0.019 \\
\hline Prunus dulcis (Mill.) D. A. Webb & 456 & 228.0 & 0.684 \\
\hline Prunus laurocerasus $\mathrm{L}$. & 44 & 22.0 & 0.110 \\
\hline Prunus persica (L.) Batsch & 39.3 & 19.7 & 0.020 \\
\hline Prunus serrulata Lindl. & 121 & 60.3 & 0.362 \\
\hline Punica granatum $\mathrm{L}$. & 26.5 & 13.3 & 0.172 \\
\hline Quercus ilex $\mathrm{L}$. & 633 & 316.6 & 68.07 \\
\hline Robinia pseudoacacia L. & 479 & 239.5 & 0.240 \\
\hline Sabal palmetto (Walter) Lodd. ex Schult. \& Schult. f. & 50.45 & 25.2 & 0.050 \\
\hline Tilia $\times$ europaea L. & 1012 & 506.1 & 48.08 \\
\hline \multicolumn{3}{|l|}{ Total C } & 340.0 \\
\hline
\end{tabular}


Table 4. The aboveground biomass $(\mathrm{AB})$, carbon stored in the aboveground biomass $\left(\mathrm{C}_{\mathrm{A}}\right)$ and the total carbon stored for each of the considered species inside the Experimental Botanical Garden.

\begin{tabular}{|c|c|c|c|}
\hline Experimental Botanical Garden & $\mathrm{AB}(\mathrm{Kg})$ & $\mathrm{C}_{\mathrm{A}}(\mathrm{Kg})$ & $\mathrm{C}_{\text {Atot }}$ per species $(\mathrm{Mg})$ \\
\hline \multicolumn{4}{|l|}{ Species } \\
\hline Abies alba Mill. & 216.9 & 108 & 0.108 \\
\hline Aesculus hippocastanum $\mathrm{L}$. & 976 & 488 & 0.488 \\
\hline Albizzia julibrissin Durazz. & 1688 & 844 & 0.844 \\
\hline Acacia horrida (L.) Willd. & 245 & 123 & 0.123 \\
\hline Acer pseudoplatanus $\mathrm{L}$. & 1236 & 618 & 0.618 \\
\hline Araucaria bidwillii Hook. & 975 & 488 & 0.488 \\
\hline $\begin{array}{l}\text { Brachychiton acerifolius (A. Cunn. ex G. Don) F. } \\
\text { Muell. }\end{array}$ & 275 & 137 & 0.275 \\
\hline Cedrus atlantica (Endl.) Manetti ex Carrière & 627 & 313 & 0.313 \\
\hline Celtis australis $\mathrm{L}$. & 688 & 344 & 1.376 \\
\hline Celtis bungeana Blume & 272 & 136 & 0.136 \\
\hline Ceratonia siliqua $\mathrm{L}$. & 229 & 114 & 0.229 \\
\hline Chamaerops humilis $\mathrm{L}$. & 50 & 25 & 0.149 \\
\hline Cinnamomum camphora (L.) J. Presl & 3353 & 1676 & 3.353 \\
\hline Citrus $\times$ aurantium $\mathrm{L}$. & 8.7 & 4.3 & 0.013 \\
\hline Citrus deliciosa Ten. & 3.5 & 1.8 & 0.007 \\
\hline Citrus limon (L.) Osbeck & 6.9 & 3.5 & 0.010 \\
\hline Citrus maxima (Burm.) Merr. & 21.3 & 10.7 & 0.011 \\
\hline Cupressus sp. & 2159.2 & 1079.6 & 2.159 \\
\hline Diospyros lotus $\mathrm{L}$. & 587 & 293 & 0.293 \\
\hline Eriobotrya japonica (Thunb.) Lindl. & 135 & 68 & 0.068 \\
\hline Eucaliptus viminalis Labill. & 265 & 132 & 0.265 \\
\hline Fagus sylvatica L. & 1125 & 562 & 2.249 \\
\hline Firmiana simplex (L.) W. Wight & 185 & 92 & 0.092 \\
\hline Fraxinus excelsior $\mathrm{L}$. & 365 & 182 & 0.182 \\
\hline Ginkgo biloba L. & 607 & 304 & 0.607 \\
\hline Jacaranda mimosifolia D. Don & 333 & 167 & 0.167 \\
\hline Magnolia grandiflora $\mathrm{L}$. & 252 & 126 & 0.126 \\
\hline Melia azedarach $\mathrm{L}$. & 547 & 273 & 0.273 \\
\hline Morus alba L. & 1087 & 543 & 0.543 \\
\hline Morus nigra $\mathrm{L}$. & 663 & 331 & 0.331 \\
\hline $\begin{array}{l}\text { Nolina longifolia (Karw. ex Schult. \& Schult. f.) } \\
\text { Hemsl. }\end{array}$ & 76.6 & 38.3 & 0.038 \\
\hline Olea europaea L. & 166.6 & 83.3 & 0.167 \\
\hline$P$. pinea $\mathrm{L}$. & 3284.8 & 1642.4 & 3.285 \\
\hline Phoenix canariensis Chabaud & 173.6 & 86.8 & 0.174 \\
\hline Phytolacca dioica L. & 321.3 & 160.7 & 0.321 \\
\hline Pinus brutia Ten. & 1147.6 & 573.8 & 0.574 \\
\hline
\end{tabular}




\begin{tabular}{|c|c|c|c|}
\hline Continued & & & \\
\hline Pinus canariensis $\mathrm{C} . \mathrm{Sm}$. & 623.3 & 311.7 & 0.312 \\
\hline Pinus eldarica Medw. & 1103.8 & 551.9 & 0.552 \\
\hline Pinus halepensis Mill. & 339.9 & 169.9 & 0.170 \\
\hline Pinus pinaster Aiton & 774.9 & 387.4 & 0.387 \\
\hline Pinus rigida Mill. & 1066.1 & 533.0 & 0.533 \\
\hline Platanus orientalis $\mathrm{L}$. & 8020.3 & 4010.1 & 4.010 \\
\hline Quercus ilex L. & 948.9 & 474.4 & 0.95 \\
\hline Quercus suber $\mathrm{L}$. & 3253 & 1627 & 1.63 \\
\hline Quercus trojana Webb & 1566 & 783 & 0.78 \\
\hline Schinus polygama (Cav.) Cabrera & 321 & 160 & 0.16 \\
\hline Taxus baccata $\mathrm{L}$. & 111 & 56 & 0.17 \\
\hline Tilia platyphyllos Scop. & 1363 & 681 & 0.68 \\
\hline Trachycarpus takil Becc. & 117 & 59 & 0.117 \\
\hline Ulmus sp. & 1355 & 678 & 0.678 \\
\hline $\begin{array}{l}\text { Washingtonia filifera (Linden ex André) } \\
\text { H. Wendl. ex de Bary }\end{array}$ & 193 & 69 & 0.206 \\
\hline Total C & & & 32 \\
\hline
\end{tabular}

ilex and T. $\times$ europaea contribute by $20 \%, 18 \%$ and $13 \%$, respectively. The highest contribution by C. deodara, Q. ilex and T. $\times$ europaea is justified by the large $\mathrm{DBH}$ and the high number of trees per species. The tree-lined avenues in the Campus have a total length of $835 \mathrm{~m}$. In particular, Q. ilex C storage of the tree-lined avenues ( $520 \mathrm{~m}$ total length) is $68.07 \mathrm{Mg}$ of $\mathrm{C}$ and by $T . \times$ europaea of the tree-lined avenues ( $315 \mathrm{~m}$ total length), $43.52 \mathrm{Mg}$ of $\mathrm{C}$. $P$. pinea $\mathrm{C}$ storage ranges from $0.40 \mathrm{Mg}$ of $\mathrm{C}$ in 15-years old trees to $106.20 \mathrm{Mg}$ of $\mathrm{C}$ in 100 -years-old trees, according to the results of [48] for the same species. In the Garden there are 83 trees stocking $32 \mathrm{Mg}$ of $\mathrm{C}$, the centenarian $P$. orientalis giving the highest contribution ( $4010 \mathrm{Kg}$ of $\mathrm{C}$ ). Moreover, trees at $\mathrm{B}$ and $\mathrm{C}$ sites reduce the mean yearly $\mathrm{CO}_{2}$ concentration by $13 \%$ compared to streets outside the Campus, which are characterized by all day high traffic level (25 \pm 5 vehicles $\min ^{-1}$, mean value during the study period), as confirmed by the significant positive correlation between the two variables. The highest $\mathrm{CO}_{2}$ concentration was monitored in winter (549 $\pm 15 \mathrm{ppm})$ decreasing by $17 \%$ and $20 \%$ in spring and summer, respectively.

The results highlight also the role of trees in reducing noise level. Noise is considered the third most serious kind of pollution because it affects human health unfavourably both physically and psychologically. General annoyance, disturbance in psychosocial well-being and reduction in sleep quality are commonly reported effects of noise exposure [49]. The mechanism of noise attenuation by plants is due to the capability of leaves to absorb acoustic energy by transferring the kinetic energy which vibrates air molecules in a sound field to the vibration pattern of leaves [50] [51] [52]. In particular, B site (Garden) de- 
creases noise level by $44 \%$ compared to A site ( $81 \pm 4 \mathrm{db})$. Areas characterized by a noise level above $65 \mathrm{~dB}$ are considered "black areas", while a noise level between 55 and $65 \mathrm{~dB}$ are "grey areas" [53]. The noise level monitored in C (54 \pm 2 $\mathrm{dB}$, mean value during the study period) follows in the "grey areas", thus resulting in a more comfortable environment for people.

\section{Conclusion}

Despite the importance of green areas in improving urban air quality, up to date, few attention has been paid to the role of the greening in Universities. The planning of these areas has been considered only from an ornamental point of view with the aim to create a "beautiful and relaxing environment". In addition, the preservation of biodiversity has become an important driver in many contemporary landscapes. Thus, the conservation of tree species and spreading information on their capability of environmental quality amelioration contribute to sensitize the public and, in particular, young people on the importance of naturalistic conservation. Our research highlighted that trees inside the Campus contribute significantly to create a healthy environment where people can reach a satisfactory wellbeing. The results, including tree traits and their air amelioration capability, can be incorporated in a database to monitor plant response over time also in consideration of changing environmental conditions. The Campus of the Sapienza University of Rome through the conservation of its collections, supported by scientific research, is a preferential way to spread information not only on plant biodiversity but also on its environmental quality amelioration.

\section{Conflicts of Interest}

The authors declare no conflicts of interest regarding the publication of this paper.

\section{References}

[1] Dobbs, C., Escobedo, F.J. and Zipperer, W.C. (2011) A Framework for Developing Urban Forest Ecosystem Services and Goods Indicators. Landscape and Urban Planning, 99, 196-206. https://doi.org/10.1016/j.landurbplan.2010.11.004

[2] Rey Gozalo, G., Barrigón Morillas, J.M., Montes González, D. and Moraga, P.A. (2018) Relationships among Satisfaction, Noise Perception, and Use of Urban Green Spaces. Science of The Total Environment, 624, 438-450. https://doi.org/10.1016/j.scitotenv.2017.12.148

[3] UN (United Nations) (2014) World Urbanization Prospects: The 2014 Revision. United Nations, Department of Economic and Social Affairs, Population Division, New York.

[4] EC (European Commission) (2000) Towards a Local Sustainability Profile: European Common Indicators. Office for Official Publications of the European Communities, Luxembourg.

[5] Nowak, D.J., Hoehn, R.E., Crane, D.E., Stevens, J.C., Walton, J.T. and Bond, J. (2008) A Ground-Based Method of Assessing Urban Forest Structure and Ecosystem Services. Agence universitaire de la Francophonie, 34, 347-358. 
[6] Gratani, L., Varone, L. and Bonito, A. (2016) Carbon Sequestration of Four Urban Parks in Rome. Urban Forestry \& Urban Greening, 19, 184-193. https://doi.org/10.1016/j.ufug.2016.07.007

[7] Gratani, L., Catoni, R., Puglielli, G., Varone, L., Crescente, M.F., Sangiorgio, S. and Lucchetta, F. (2016) Carbon Dioxide $\left(\mathrm{CO}_{2}\right)$ Sequestration and Air Temperature Amelioration Provided by Urban Parks in Rome. Energy Procedia, 101, 408-415. https://doi.org/10.1016/j.egypro.2016.11.052

[8] Maas, J., van Dillen, S.M.E., Verheij, R.A. and Groenewegen, P.P. (2009) Social Contacts as a Possible Mechanism behind the Relation between Green Space and Health. Health \& Place, 15, 586-595.

https://doi.org/10.1016/j.healthplace.2008.09.006

[9] Peters, K., Elands, B. and Buijs, A. (2010) Social Interactions in Urban Parks: Stimulating Social Cohesion? Urban Forestry \& Urban Greening, 9, 93-100. https://doi.org/10.1016/j.ufug.2009.11.003

[10] Dadvand, P., Nieuwenhuijsen, M.J., Esnaola, M., Forns, J., Basagaña, X., Alvarez-Pedrerol, M., Rivas, I., López-Vicente, M., Pascual, M.D.C. and Su, J. (2015) Green Spaces and Cognitive Development in Primary Schoolchildren. Proceedings of the National Academy of Sciences of the United States of America, 112, 7937-7942. https://doi.org/10.1073/pnas.1503402112

[11] Grahn, P. and Stigsdotter, U.A. (2003) Landscape Planning and Stress. Urban Forestry \& Urban Greening, 2, 1-18. https://doi.org/10.1078/1618-8667-00019

[12] Jay, M. and Schraml, U. (2009) Understanding the Role of Urban Forests for Migrants-Uses, Perception and Integrative Potential. Urban Forestry \& Urban Greening, 8, 283-294. https://doi.org/10.1016/j.ufug.2009.07.003

[13] Millward, A.A. and Sabir, B. (2011) Benefits of a Forested Urban Park: What Is the Value of Allan Gardens to the City of Toronto, Canada? Landscape and Urban Planning, 100, 177-188. https://doi.org/10.1016/j.landurbplan.2010.11.013

[14] Nowak, D.J. and Crane, D.E. (2002) Carbon Storage and Sequestration by Urban Trees in the USA. Environmental Pollution, 116, 381-389. https://doi.org/10.1016/S0269-7491(01)00214-7

[15] Gratani, L. and Varone, L. (2006) Carbon Sequestration by Quercus ilex L. and Quercus pubescens Willd. and Their Contribution to Decreasing Air Temperature in Rome. Urban Ecosystems, 9, 27-37. https://doi.org/10.1007/s11252-006-5527-2

[16] Gratani, L. and Varone, L. (2007) Plant Crown Traits and Carbon Sequestration Capability by Platanus hybrida Bront in Rome. Landscape and Urban Planning, 81, 282-286. https://doi.org/10.1016/j.landurbplan.2007.01.006

[17] Woodall, C.W., Nowak, D.J., Liknes, G.C. and Westfall, J.A. (2010) Assessing the Potential for Urban Trees to Facilitate Forest Tree Migration in the Eastern United States. Forest Ecology and Management, 259, 1447-1454. https://doi.org/10.1016/j.foreco.2010.01.018

[18] Gratani, L., Crescente, M.F. and Varone, L. (2008) Long-Term Monitoring of Metal Pollution by Urban Trees. Atmospheric Environment, 42, 8273-8277. https://doi.org/10.1016/j.atmosenv.2008.07.032

[19] Yin, S., Shen, Z., Zhou, P., Zou, X., Che, S. and Wang, W. (2011) Quantifying Air Pollution Attenuation within Urban Parks: An Experimental Approach in Shanghai, China. Environmental Pollution, 159, 2155-2163. https://doi.org/10.1016/j.envpol.2011.03.009

[20] Cohen, P., Potchter, O. and Schnell, I. (2014) The Impact of an Urban Park on Air Pollution and Noise Levels in the Mediterranean City of Tel-Aviv, Israel. Environ- 
mental Pollution, 195, 73-83. https://doi.org/10.1016/j.envpol.2014.08.015

[21] Chiesura, A. (2004) The Role of Urban Parks for the Sustainable City. Landscape and Urban Planning, 68, 129-138.

https://doi.org/10.1016/j.landurbplan.2003.08.003

[22] Nagendra, H. and Gopal, D. (2011) Tree Diversity, Distribution, History and Change in Urban Parks: Studies in Bangalore, India. Urban Ecosystems, 14, 211-223. https://doi.org/10.1007/s11252-010-0148-1

[23] Gratani, L. and Varone, L. (2013) Carbon Sequestration and Noise Attenuation Provided by Hedges in Rome: The Contribution of Hedge Traits in Decreasing Pollution Levels. Atmospheric Pollution Research, 4, 315-322. https://doi.org/10.5094/APR.2013.035

[24] McHale, M., Burke, I., Lefsky, M., Peper, P. and McPherson, G. (2009) Urban Forest Biomass Estimates: It Is Important to Use Allometric Relationships Developed Specifically for Urban Trees? Urban Ecosystems, 12, 95-113. https://doi.org/10.1007/s11252-009-0081-3

[25] Dwyer, J.F., Nowak, D.J. and Noble, M.H. (2003) Sustaining Urban Forests. Journal of Arboriculture, 29, 49-55.

[26] McHale, M., McPherson, E.G. and Burke, I. (2007) The Potential of Urban Tree Plantings to Be Cost Effective in Carbon Credit Markets. Urban Forestry \& Urban Greening, 6, 49-60. https://doi.org/10.1016/j.ufug.2007.01.001

[27] McPherson, E.G. and Peper, P. (2012) Urban Tree Growth Modeling. Arboriculture \& Urban Forestry, 38, 172-180.

[28] Frank, S., Glenn, W., Beer, R. and Peter, M. (2006) An Analysis of the Street Tree Population of Greater Melbourne at the Beginning of the 21st Century. Arboriculture \& Urban Forestry, 32, 155-163.

[29] Moore, G. (2009) People, Trees, Landscapes and Climate Change. Climate Change: On for Young and Old. 131-149. https://www.futureleaders.com.au

[30] Lau, S.S.Y. and Yang, F. (2009) Introducing Healing Gardens into a Compact University Campus: Design Natural Space to Create Healthy and Sustainable Campuses. Landscape Research, 34, 55-81. https://doi.org/10.1080/01426390801981720

[31] Idso, C.D., Idso, S.B. and Balling Jr., R.C. (2001) An Intensive Two-Week Study of an Urban $\mathrm{CO}_{2}$ Dome in Phoenix, Arizona, USA. Atmospheric Environment, 35 , 995-1000. https://doi.org/10.1016/S1352-2310(00)00412-X

[32] Tabacchi, G., Di Cosmo, L., Gasparini, P. and Morelli, S. (2011) Stima del volume e della fitomassa delle principali specie forestali italiane. Equazioni di previsione, tavole del volume e tavole della fitomassa arborea epigea. Consiglio per la Ricerca e la sperimentazione in Agricoltura, Unità di Ricerca per il monitoraggio e la pianificazione Forestale, Trento.

[33] Gratani, L., Pesoli, P., Crescente, M.F. and Tinelli, A. (2001) Analisi della struttura di Pinus pinea L. in funzione dell'età: Variazione dell'indice di area fogliare (LAI) e della morfologia degli aghi. Accademia nazionale delle Scienze detta dei Quaranta Roma.

[34] Gratani, L., Bombelli, A. and Covone, F. (2003) Variation in Shrub Structure and Species Co-Occurrence in the Mediterranean Maquis. Journal of Mediterranean Ecology, 4, 31-37.

[35] Marin-Spiotta, E., Ostertag, R. and Silver, W.L. (2007) Long-Term Patterns in Tropical Reforestation: Plant Community Composition and Aboveground Biomass Accumulation. Ecological Applications, 17, 828-839. 
https://doi.org/10.1890/06-1268

[36] Liu, L., Guan, D., Peart, M.R., Wang, G., Zhang, H. and Li, Z. (2013) The Dust Retention Capacities of Urban Vegetation-A Case Study of Guangzhou, South China. Environmental Science and Pollution Research, 20, 6601-6610. https://doi.org/10.1007/s11356-013-1648-3

[37] Pietropaoli, S. (2014) Mesocosmi sperimentali per lo studio dei processi fisiologici di specie arboree forestali nell'ambito della fitodepurazione: Recupero di acque contaminate per la produzione di biomassa legnosa.

[38] IPCC (2003) Good Practice Guidance for Land Use, Land-Use Change and Forestry. IPCC Technical Support Unit, Kanagawa, Japan.

[39] Stagoll, K., Lindenmayer, D.B., Knight, E., Fischer, J. and Manning, A.D. (2012) Large Trees Are Keystone Structures in Urban Parks. Conservation Letters, 5, 115-122. https://doi.org/10.1111/j.1755-263X.2011.00216.x

[40] Nowak, D.J., Hirabayashi, S., Doyle, M., McGovern, M. and Pasher, J. (2018) Air Pollution Removal by Urban Forests in Canada and Its Effect on Air Quality and Human Health. Urban Forestry \& Urban Greening, 29, 40-48.

https://doi.org/10.1016/j.ufug.2017.10.019

[41] Loughner, C.P., Allen, D.J., Zhang, D.-L., Pickering, K.E., Dickerson, R.R. and Landry, L. (2012) Roles of Urban Tree Canopy and Buildings in Urban Heat Island Effects: Parameterization and Preliminary Results. Journal of Applied Meteorology and Climatology, 51, 1775-1793. https://doi.org/10.1175/JAMC-D-11-0228.1

[42] Hennessy, J.T., Gibbens, R.P., Tromble, J.M. and Cardenas, M. (1985) Mesquite (Prosopis grandulosa Torr.) Dunes and Interdunes in Southern New Mexico: A Study of Soil Properties and Soil Water Relations. Journal of Arid Environments, 9, 27-38. https://doi.org/10.1016/S0140-1963(18)31269-2

[43] Scholes, R.J. and Archer, S.R. (1997) Tree-Grass Interactions in Savannas. Annual Review of Ecology and Systematics, 28, 517-544.

https://doi.org/10.1146/annurev.ecolsys.28.1.517

[44] Snyder, K.A., Mitchell, K.A. and Herrick, J.E. (2006) Patterns and Controls of Soil Water in the Jornada Basin. In: Havstad, K.M., Huenneke, L.F. and Schlesinger, W.H., Eds., Structure and Function of a Chihuahuan Desert Ecosystem: The Jornada Basin Long-Term Ecological Research Site, Oxford University Press, New York, 107-132.

[45] Escobedo, F., Varela, S., Zhao, M., Wagner, J. and Zipperer, W. (2010) Analyzing the Efficacy of Subtropical Urban Forests in Offsetting Carbon Emissions from Cities. Environmental Science \& Policy, 13, 362-372. https://doi.org/10.1016/j.envsci.2010.03.009

[46] Koerner, B. and Klopatek, J. (2002) Anthropogenic and Natural $\mathrm{CO}_{2}$ Emission Sources in an Arid Urban Environment. Environmental Pollution, 116, 45-51. https://doi.org/10.1016/S0269-7491(01)00246-9

[47] Rowntree, R.A. and Nowak, D.J. (1991) Quantifying the Role of Urban Forests in Removing Atmospheric Carbon Dioxide. Journal of Arboriculture, 17, 269-275.

[48] Gratani, L., Crescente, M.F., Varone, L., Bonito, A. and Tinelli, A. (2015) Pinus pinea L. Plant Trait Variations in Response to Tree Age and Silvicultural Management and Carbon Storage Capability. Rendiconti Lincei, 26, 507-515. https://doi.org/10.1007/s12210-014-0343-8

[49] Sun, K., De Coensel, B., Echevarria Sanchez, G.M., Van Renterghem, T. and Botteldooren, D. (2018) Effect of Interaction between Attention Focusing Capability and Visual Factors on Road Traffic Noise Annoyance. Applied Acoustics, 134, 16-24. 
https://doi.org/10.1016/j.apacoust.2018.01.001

[50] Yang, J. and Gan, W.S. (2001) On the Actively Controlled Noise Barrier. Journal of Sound and Vibration, 240, 592-597. https://doi.org/10.1006/jsvi.2000.3162

[51] Maleki, K., Hosseini, S.M. and Nasiri, P. (2010) The Effect of Pure and Mixed Plantations of Robinia pseudoacacia and Pinus eldarica on Traffic Noise Decrease. International Journal of Environmental Science, 1, 213-224.

[52] Pathak, V., Tripathi, B.D. and Mishra, V.K. (2011) Evaluation of Anticipated Performance Index of Some Tree Species for Green Belt Development to Mitigate Traffic Generated Noise. Urban Forestry \& Urban Greening, 10, 61-66. https://doi.org/10.1016/j.ufug.2010.06.008

[53] Gidlöf-Gunnarsson, A. and Öhrström, E. (2007) Noise and Well-Being in Urban Residential Environments: The Potential Role of Perceived Availability to Nearby Green Areas. Landscape and Urban Planning, 83, 115-126.

https://doi.org/10.1016/j.landurbplan.2007.03.003 